REFLECTIONS:

NEUROLOGY AND

THE HUMANITIES

Section Editor

Anne W. McCammon,

MD, FAAN

Margot Hedlin, BS

Correspondence to

M. Hedlin:

margot_hedlin@med.unc.edu

\title{
Your mind is somewhere, but it's not here
}

You don't remember me, but I was the medical student crying in the back of the room. The admission note described the bike accident you had a month ago, the gradual decline in cognitive function, the seizures, the emotional lability and agitation. But that's a detached way to describe how you toss and turn in bed, imploring us to help the babies you hear crying in the neighboring room, too confused to answer our questions, too obtunded at times to even know we were there. These days your favorite toy is a pink ball, your mother says, and she strokes your head as she hands it to you, then you drop it and she gives it to you again, and you drop it again, and we look at you with our white coats and stethoscopes as she describes how you were getting honors in high school.

Your mind is somewhere, but it's not here. It's back to when you were 5 and you're learning to ride a bike, and your mother is laughing and clapping and running after you as you soar over a green field. Then you're 9 and you're sitting on the porch on a summer night, laughing as a raccoon peeks out of the gutter. Then you're 14 again and you're back with us and why does everything hurt so much, who is crying? "Go help the babies," you plead, "please, you have to." Then it's a month ago, and your dad is looking at the bike helmet that you split wide open, concerned yet proud that his son was tough enough to withstand a fall on a steep mountain trail. Then it's a week ago and you're crying because you can't solve a child's puzzle. Then you're 3 and your mom is singing to you as she cradles you in her arms, and for a moment everything is soft. "I know I'm breaking your heart," you told her last night, in one of your glimpses of lucidity.

But that's as much of your story as I'll ever know. We sent you to an academic medical center 200 miles away, in the hopes that they could at least put a name to what afflicts you. I saw your parents for a haggard moment before they left the hospital, walking out into the too-bright sunshine to follow the ambulance that took you away. I never really knew you, but I miss you all the same. 


\title{
Neurology
}

\author{
Your mind is somewhere, but it's not here \\ Margot Hedlin \\ Neurology 2017;88;e34 \\ DOI 10.1212/WNL.0000000000003531
}

This information is current as of January 23, 2017

\section{Updated Information \& Services}

\section{Subspecialty Collections}

Permissions \& Licensing

\section{Reprints}

including high resolution figures, can be found at: http://n.neurology.org/content/88/4/e34.full

This article, along with others on similar topics, appears in the following collection(s):

\section{All Pediatric}

http://n.neurology.org/cgi/collection/all_pediatric

Brain trauma

http://n.neurology.org/cgi/collection/brain_trauma

Delirium

http://n.neurology.org/cgi/collection/delirium

Intelligence

http://n.neurology.org/cgi/collection/intelligence

Palliative care

http://n.neurology.org/cgi/collection/palliative_care

Information about reproducing this article in parts (figures,tables) or in its entirety can be found online at:

http://www.neurology.org/about/about_the_journal\#permissions

Information about ordering reprints can be found online:

http://n.neurology.org/subscribers/advertise

Neurology ${ }^{\circledR}$ is the official journal of the American Academy of Neurology. Published continuously since 1951, it is now a weekly with 48 issues per year. Copyright () 2017 American Academy of Neurology. All rights reserved. Print ISSN: 0028-3878. Online ISSN: 1526-632X.

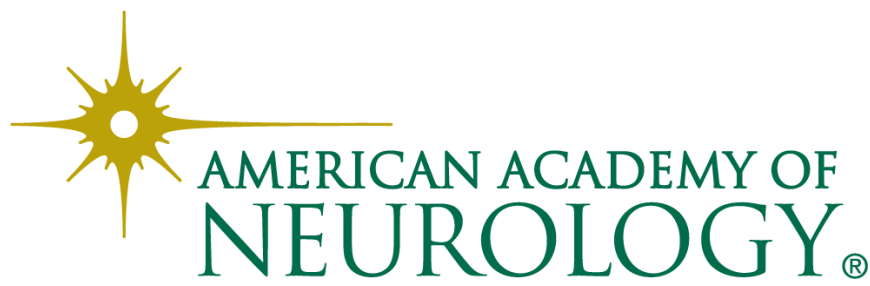

